\title{
Low serotonergic tone and elevated risk for substance misuse ${ }^{\dagger}$
}

David Nutt

\section{Summary}

Cox et al's paper addresses an issue that has long been assumed to be a central aspect of brain function - the interplay of different neurotransmitters - but for which we have very little evidence so far. It is currently unclear whether these findings will have implications for the treatment of those with cocaine or other substance dependence.

\section{Declaration of interest}

None.
David Nutt is Edmund J. Safra Professor of Neuropsychopharmacology and Director of the Neuropsychopharmacology Unit at Imperial College London. He leads an interdisciplinary research group with a particular focus on brain imaging, especially positron emission tomography. He is currently Chair of the Independent Scientific Committee on Drugs and Past-President of the European College of Neuropsychopharmacology, Vice-President of the European Brain Council, President of the British Neuroscience Association, an Editor of the Journal of Psychopharmacology and psychiatry drugs advisor to the British National Formulary.

Cox et $a l^{1}$ address an issue that has long been assumed to be a central aspect of brain function - the interplay of different neurotransmitters - but for which we have very little evidence so far. The 5-hydroxtryptamine (5-HT) system is perhaps the easiest to manipulate in that many studies have shown that simply by reducing the access of the 5-HT precursor L-tryptophan to the brain using a dietary manipulation (the tryptophan depletion technique) 5-HT function falls. This results in major alterations in brain function such as the loss of the antidepressant and anxiolytic effect of selective serotonin reuptake inhibitors (SSRIs) ${ }^{2}$ and the shortening of rapid eye movement (REM) sleep latency. ${ }^{3}$ However, by and large, such changes in 5-HT function have not revealed much evidence of significant interactions with other neurotransmitters. In particular, when the tryptophan depletion approach was used to test a 5-HT link in the action of noradrenaline-acting antidepressants no measureable interaction was detected. ${ }^{4}$

So is dopamine different? It seems that this might be the case as in Cox et al's ${ }^{1}$ study lowering 5 -HT function by tryptophan depletion led to a reduction in the actions of cocaine to release dopamine that was to some extent paralleled by a reduction in cocaine craving. This finding fits with some preclinical literature that suggests 5-HT restrains dopamine neuronal function, which is sometimes seen clinically when elevating 5 -HT by SSRIs causes symptoms attributable to low dopamine function such as akathisia and dystonias.

Low brain 5-HT function has long been associated with impulsive and aggressive traits ${ }^{5}$ that themselves may be predictors of stimulant misuse. The possibility that cocaine users might exacerbate their addiction by being in a state of relative L-tryptophan deficiency from poor diet and reduced appetite should also be considered.

'See pp. 391-397, this issue.

\section{Implications for practice}

Whether these new findings will contribute to the treatment options for cocaine or other stimulant dependence is less clear. In general, SSRIs have proved ineffective as anti-addiction agents except where they ameliorate primary anxiety or depressive disorders. ${ }^{6}$ The magnitude of the modulatory effect of 5-HT to limit dopamine release may be too little to offset the major impact of cocaine, which in preclinical studies can increase brain dopamine release up to ten-fold.

It also asks the question, to what extent might 5-HT regulate the effects of other drugs of addiction. Preclinical studies lead us to believe that 5-HT is central to the actions of MDMA (3,4-methylenedioxymethamphetamine) and psychedelics but this has been little explored in humans, and interactions with other drugs of misuse such a heroin and alcohol for which dopamine is less important might also repay investigation. In addition, future studies should consider the possible contribution of genetic variations in 5-HT functionality. Obvious targets are polymorphisms of the 5-HT reuptake site ('ss' or 'll' variants) or those of tryptophan hydroxylase-2 (the main synthetic enzyme for 5 -HT).

David Nutt, DM, FRCP, FRCPsych, FMedSci, Neuropsychopharmacology Unit, Centre for Pharmacology and Therapeutics, Department of Medicine, Imperial College London, Burlington-Danes Building, Hammersmith Hospital, Du Cane Road, London W12 ONN, UK. Email: d.nutt@imperial.ac.uk

First received 19 Apr 2011, final revision 18 Jul 2011, accepted 28 Jul 2011

\section{References}

1 Cox SML, Benkelfat C, Dagher A, Delaney JS, Durand F, Kolivakis T, et al. Effects of lowered serotonin transmission on cocaine-induced striatal dopamine response: PET $\left[{ }^{11} \mathrm{C}\right]$ raclopride study in humans. $\mathrm{Br} J$ Psychiatry 2011; 199: 391-7

2 Bell C, Abrams J, Nutt D. Tryptophan depletion and its implications for psychiatry. Br J Psychiatry 2001; 178: 399-405.

3 Evans L, Golshan S, Kelsoe J, Rapaport M, Resovsky K, Sutton L, et al. Effects of rapid tryptophan depletion on sleep electroencephalogram and mood in subjects with partially remitted depression on bupropion. Neuropsychopharmacology 2002; 27: 1016-26.

4 Delgado P, Miller HL, Salomon RM, Licinio J, Krystal JH, Moreno FA, et al. Tryptophan-depletion challenge in depressed patients treated with desipramine or fluoxetine: implications for the role of serotonin in the mechanism of antidepressant action. Biol Psychiatry 1999; 46 212-20. 
5 Virkkunen M, Rawlings R, Tokola R, Poland RE, Guidotti A, Nemeroff C, et al. CSF biochemistries, glucose metabolism, and diurnal activity rhythms in alcoholic, violent offenders, fire setters, and healthy volunteers. Arch Gen Psychiatry 1994; 51: 20-7.
6 Lingford-Hughes AR, Welch S, Nutt DJ, British Association for Psychopharmacology. Evidence-based guidelines for the pharmacological management of substance misuse, addiction and comorbidity. J Psychopharmacol 2004; 18: 293-335.

\section{Poems by doctors}

\section{The Last Vision of Angus McKay}

\section{Tom Pow}

Angus McKay, Queen Victoria's piper, went insane 'over study of music'. He was admitted to the Crichton Royal from Bedlam in 1856 when he was 43 years old. 'His most prominent delusion is that Her Majesty is his wife and that Prince Albert has defrauded him of his rights.' (Crichton case notes)

Let it be noted (in copperplate), Angus McKay is a gentleman to watch. The stoutest furniture is firewood to him; a mattress, within a day, he'll disembowel. He has been known to drink his own urine; to spit, shriek, howl and hoot like an owl:

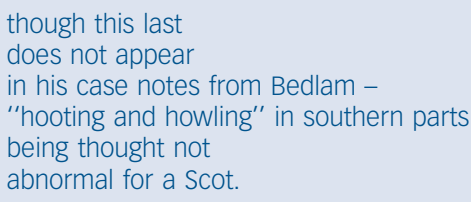

Nevertheless, there is enough on his native ground to amaze and perplex his keepers.

Fuck it! Angus McKay has done with them all.

He eases himself into the rivercold waters of the Nith across which lies Kirkconnell Wood and his freedom. At that moment

(to which the record is blind

no body being found, never mind testament forthcoming)

something catches his eye - a sudden flurry and a bird with two necks intertwined; one black, the other bodiless - a shimmering Islay malt brown.

Angus McKay watches, mesmerised

as the cormorant lifts its white-cheeked head till its brassy twin - the eel - lifting with it, unwinds like a flailing clef and falls, bit by bit, into perfect darkness.

This, thinks Angus McKay, is how the bagpipe has devoured my life.

He lies on his back, drifting downstream,

shadowing the black bag of a bird through flanges of light, past two gracefully disinterested swans. The eel rages still -

the cormorant's neck rising and falling in a helpless hiccup. Up ahead, the bird will calm, its neck settle again on its shoulders -

but there, the quicksand waits to welcome Angus McKay, sipping him, limb by limb, into its dark and clammy hold.

That evening, owls will keen - in Gaelic from Kirkconnell Wood, where Angus McKay perches, pale and dripping.

Will a soul never find peace? he asks.

Oh, where has my plump little lover gone -

and what's become of that shit, Prince Albert?

From Dear Alice - Narratives of Madness (Salt, 2008). We have also published two other poems by Tom Pow, The Great Asylums of Scotland (June 2011) and Night watch, 1842 (September 2011). Reproduced with permission from Salt Publishing Limited (c) Tom Pow. Chosen by Femi Oyebode. 